
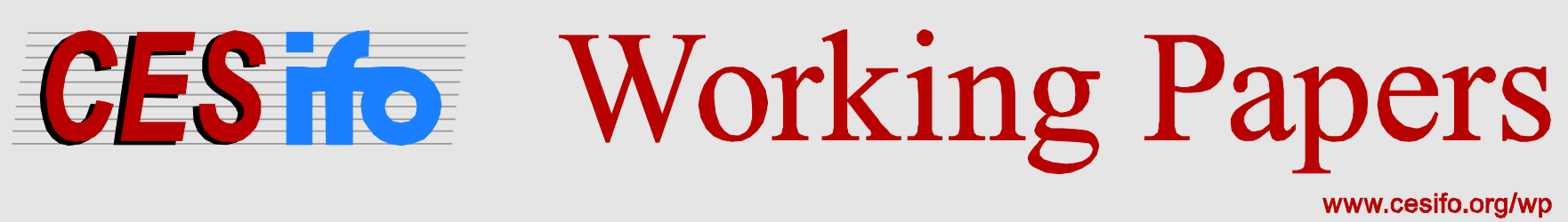

\title{
Public Choice and Public Finance: A Survey
}

\author{
Charles B. Blankart
}

\author{
CESIFO WORKING PAPER No. 5819 \\ CATEgORY 2: Public CHOICE \\ MARCH 2016
}

An electronic version of the paper may be downloaded

- from the SSRN website:

- from the RePEc website:

- from the CESifo website:

wWw.SSRN.com

www.RePEc.org

www.CESifo-group.org/wp 


\title{
Public Choice and Public Finance: A Survey
}

\author{
Abstract \\ JEL-Codes: D720. \\ Charles B. Blankart \\ Humboldt-University Berlin \\ Spandauer Str. 1 \\ Germany - 10178 Berlin \\ charles@blankart.net
}

The paper highlights the origins of Public Choice as a descendant of Public Finance.

March 8, 2016 
Public Choice and Public Finance: A Survey

by

Charles B. Blankart

Humboldt-University Berlin

I. The Sources of Public Choice

In the Wealth of Nations published in 1776, Adam Smith convincingly explains the fundamental importance of freedom for the prosperity of the people of a nation. Incidentally the year of the publication of the Wealth of Nations coincides with the year of Declaration of Independence of the United States of America. Not incidentally, however, Adam Smith's book has enormously inspired the US Constitution framers in writing the Federalist papers in the years 1787/8. In Britain, Smith's home country, the echo of the Wealth of Nations was more mixed. Adam Smith has been praised as an anti-mercanitilist. But his commitment for liberty has become less acknowledged. Smith had to convince his compatriot readers against the theories of competing writers. In 1789 , only a few years after the publication of the Wealth of Nations, Jeremy Bentham has published his "Introduction to the Principles of Morals and Legislation" in which he proposed utilitarianism as a leading doctrine for the British public. Bentham fought for a moral society against phenomena as usury and prodigality. His follower John Stuart Mill saw utilitarianism as a principle to obtain a better society. One of Mill's principles was that of an equal sacrifice which rich and poor citizens should contribute to the state in 
order to obtain a happier and hence better society. As utility of income and wealth was assumed to decline with higher income, Mill's equal sacrifice principle implied a higher taxation of the rich compared to the taxation of the poor. The amount of the total sacrifice, in fact the amount of money to be raised has not been questioned. Therefore the public choice has remained outside economic analysis. Bentham and Mill both had a large influence in Britain. It is due to their publications that utilitarianism has become a leading philosophy in $19^{\text {th }}$ up to the $20^{\text {th }}$ century Britain. As utility was regarded as cardinally measurable welfare maximization became a policy goal for governments. Welfare maximization had its own justification. It was imposed and hence independent of individuals' choices. So the spirit of liberty of Adam Smith has been crowded out of public policy.

The utilitarian view was contested by three neoclassical economists Carl Menger of Vienna, Stanley Jevons of London and Léon Walras of Lausanne who succeeded in explaining prices in a market economy as a result of consistent individual market evaluations of private goods around 1870. But individual market evaluations were alien to the British utilitarians (Blankart 2014). Therefore the three neoclassical economists had little success in Britain. They missed to notice that the great neoclassical trias has opened a new research program from private to public goods. The study of the economics of public goods has been exiled to the Continent to Germany, Italy and Sweden.

In Germany Adolf Wagner of Berlin was an important trailblazer. Wagner did not believe much in the relevance of individual choices in the public sector, but he understood the relevance or public goods which were unknown to the then leading British public finance economists Bentham and Mill (see Blaug 1978). On the one hand Wagner gave an important signal to the economists of the Italian School of public finance to study public goods on the basis of the marginal utility which they appreciated from reading the publications of the neoclassical economists Menger, Jevons and Walras. On the other hand the Italians have already been familiar to think in terms of quid pro quo for public goods.

Marchese De Viti de Marco (1888) and Ugo Mazzola (1890) concluded that the principle of choice had to be extended from private goods to public goods: This was a new world quite different from the utilitarian world of Bentham and Mill. But how should choice be organized as public goods were consumed collectively? All individuals had to contribute according their joint evaluation, said De Viti de Marco, and each individual according to his own evaluation according his "godimento" as Mazzola has suuggested. How could this bridge be built? De Viti de Marco thought that the actual state should become something as a cooperative. Mazzola thought that coercion is necessary (Fausto, 2006, p. 77)). But coercion would disregard the idea of individual evaluation: in fact the heart of the whole Italian scientific venture. No doubt: Marginal evaluation had to be 
voluntary. At this critical point the Swedish economist Knut Wicksell has made the decisive contribution. He has linked the idea of quid pro quo inherited from Ferrara and Sax and combined it with the institutions of the parliamentary decision process:

"The principle is as such nothing, but the interest principle, the well known principle of reciprocity between contribution and return whose range of application and usefulness I try to extend in two directions; On the one hand, following the example of Sax and his followers, towards applying the modern view of marginal utility and of subjective evaluation consistently to public services and private individuals' response payments ... and - as my own and original idea - ...the principle of taxation in connection to way of parliamentary tax approval." (Wicksell 1896, introduction p. vi - vii, author's own translation.)

For Wicksell it was necessary that individuals' consent is voluntary. So the link to neoclassical economics was established, and the result was indeed a choice. Wicksell has effectively closed the gap from private to of public goods, the problem which was left open by Menger, Jevons and Walras who only considered private goods. The importance of linking choice from private to public goods has never been fully grasped by the established Anglo-Saxon-School of public finance. Even nowadays James Mirrlees, e.g, acknowledges the existence of public goods in Diamond and Mirrlees (1971). Mirrlees reserves an amount of resources for public goods in his theory of optimal taxation. But how public goods should be evaluated and decided is omitted in the Mirrlees model (Blankart, 2014).

The light disseminated by the Swedish-Italian economists has remained unnoticed until Richard Musgrave has popularized their views in his 1939 paper on the Voluntary Exchange Theory of Public Economy'. But the fundamental attack against the welfare approach of the Anglo-Saxon School was due to the publication of Lionel Robbins' book An Essay on the Nature and Significance of Economic Science, London (1932, 1935). Robbins argued that the economists should stop studying normative issues about the welfare of a society, but rather analyze positively how individuals use scarce means to achieve alternative ends. So Robbins has repatriated choice in the centre of economics.

Robbins gave confidence to economists studying positive economics in the new world of public choice. Duncan Black (1948) and Kenneth Arrow (1951) were the first who tested the new trail. They extended the study free markets to the study of free democracies. Their first results were a great surprise. Black found that separate individual orderings, when compared pairwise might end in a cycle. He popularized earlier, but forgotten results by the French scientist Marquis de Condorcet (1785) and the English logican Charles Dodgson (1865).

Arrow $(1951,1963)$ has proven that, when voters have to choose between three or more distinct alternatives, individual rankings cannot be converted in a consistent set of 
collectively ranked preferences if individuals' domain of alternatives is unrestricted, if dictatorship is to be absent, if Pareto efficiency and independence of irrelevant alternatives have to hold.

Of course, if one or more of the four conditions are relaxed, a consistent ordering may be feasible. The most famous invention is due to Black (1948). He found that if it is possible to array the alternatives in such a way that each voter's preferences exhibit single-peakedness, then cycling could be avoided and in fact the median voter decides for the whole community (Median Voter Theorem). Is Blacks condition realistic? Single peakedness seems plausible if the community has to decide on whether to have one, two or three football fields. The football fans on the one hand are confronted with the football grumpies on the other. But single peackedness is much less clear when the community has to decide how to use the last plot of land in a local community. Should the plot be used for a football field, an ecological park or a building site? There is no reason whatsoever that the voters have single peaked preferences (Dennis C. Mueller 2003).

Gerald Kramer (1973) asked the question: How much homogeneity of preferences is necessary to avoid a cycle. He found that only when individuals have non-crossing personal indifference curves a cycle can be avoided. This is a very strong condition. For non-crossing can be expected for one individual, but not among several individuals). Non-crossing between several individuals in fact implies unanimity between these individuals. But with unanimity, preferences are simply juxtaposed and not really aggregated. An aggregation of preferences leading us to a social welfare function as aimed by Abram Bergson (1938) or Paul A. Samuelson (1947), indicating what is good and what is bad for the society, is not possible. This again shows the importance of Arrow's impossibility theorem. A conclusion of these results is that we should not rely too much on the rationality of collective choice. In fact, we should rather avoid voting processes.

Black has shown what single majority rule cannot produce. But what can single majority rule do? More in detail, Kenneth O. May (1952) found that, under two alternatives, the sum of yes $(+1)$ and no $(-1)$ will generate a group decision function which is a simple majority rule if and only if it satisfies the following four conditions:

1. decisiveness (i.e. no ambiguity)

2. positive responsiveness (of the outcome when either the pros or the cons increase)

3. anonymity (among ballots of voters)

4. neutrality (on particular issues) (Mueller 2003: 133-36).

If we add transitivity as an additional condition it follows from May's theorem that no voting rule will satisfy all five conditions, not even the simple majority rule. In particular, decisiveness may be violated, which would mean that the outcome may be no more unambiguous. 
Neutrality means that all issues are of the same importance, anonymity that all individuals are equally affected. Dropping these two conditions opens a multidimensional issue space and hence opportunities for trading votes (logrolling) between issues of unequal importance and between individuals with different intensity of preferences. Decisiveness will break down and majority rule will lead to cycling. A further consequence of this analysis is that logrolling opens no escape from Arrow's impossibility theorem (Bernholz 1973).

Under these new conditions another set of very strict conditions has to be met to restore a stable outcome of majority rule. Charles Plott (1967) has shown that a majority rule equilibrium exists if it is a maximum for one and only one voter while the other voters are evenly paired off so that any change improving the position for one individual is balanced by another individual being made worse off (cf. Mueller 2003).

\section{Political Entrepreuneurs}

But what will individuals do? Inconsistencies of voting open new perspectives for political entrepreneurship. Anthony Downs (1957) has suggested that party leaders who maximize votes may contribute to general welfare in the same way as competitive private entrepreneurs who maximize profits under competition. So the paradigm of Adam Smith reappears in political economy. The analogy holds, however only, if the political process fulfils a number of restrictive conditions. Political issues can be arranged in a single left-right policy space consistent with Duncan Black's condition of single peakedness. Moreover perfect information and permanent voting are required. Eventually two competing parties will meet in equilibrium at the program which is most preferred by the median voter.

Chance decides which party will come to government. If individuals, however, ignore how close parties are at the median. If they believe that parties' positions are far off the median, the probability that an individual's vote is decisive for the election outcome is very small and not worth the personal costs of voting. Nevertheless people vote. This is the "paradox of voting" first found by Downs (1957). The paradox of voting is an unexplained anomaly in economics.

The Downsian conditions of a voting equilibrium are, however, very restrictive. Peter Coughlin and Shmuel Nitzan (1981) asked the question: Is it possible to find a voting equilibrium between two competing parties if preferences are more than onedimensional? They found that under deterministic preferences even small changes in a platform will motivate voters to reallocate their votes so that cycling again occurs as soon as a party transgresses the yes/no threshold of a voter's preferences. Cycling can, however, be avoided when voters and parties are both incompletely informed about each others' reactions so that only the probability of a yes or no increases or decreases 
when a party modifies its program, and voters therefore adjust their voting decisions probabilistically in each direction. Under these conditions again a stable median voter outcome may emerge.

In the more general case that the equilibrium conditions are not fulfilled, vote competition generates an endless cycle. One majority beats the other without an improvement in sight. The danger increases that individuals get frustrated and find their hope in the autocracy of a powerful dictator.

\section{The economic theory of constitutions}

What can economist propose in the bleak world of endless cycles? James Buchanan and Gordon Tullock (1962) propose the idea of a constitutional contract. A constitutional contract contains the basic rules on which the potential participants of a polity can agree. Agreement is the basis of legitimacy and stability of the polity. Those who do not agree do not take part. They may go West an establish a community elsewhere in the endless depth of the American Continent.

Buchanan was very much inspired by Knut Wicksell (1896) when he wrote chapters on the Constitution in the Calculus of Consent. Wicksell thought that a tax which is imposed by the franchized rich on the dis-enfranchized poor cannot be just. "Just taxation" (so the subtitle of Wicksell's book of 1896) had to be unanimous. Buchanan does not go so far he does not insist in justice, but only in legitimacy. He writes: "[T]the legitimacy of social-organizational structures is to be judged against the voluntary agreement of those who are to live or are living under the arrangements that are judged." (Buchanan 1999: 288). The legitimate constitutional contract is the basis from which all further arrangements have to start. It opens a perspective for further agreements. To quote Buchanan: "The central premise of individuals as sovereigns does allow for delegation of decision-making authority to agents, so long as it remains understood that individuals remain as principals." (Buchanan 1999: 288). Delegation implies the power to make less than unanimous decisions. Individuals are aware of all the intricacies of less than unanimity decisions as found by Arrow, Black, May, Kramer and others but they come to the conclusion that less than unanimity can be advantageous within the previously agreed contract. Their yes to less than unanimity decisions is encouraged by the veil of ignorance. They may correctly predict the consequences of a collective decision rule, but they are behind the veil of uncertainty and cannot predict whether they will be on the winning or on the losing side of a coalition. Therefore they can separate the characteristics of the rule from their personal interests which are disguised.

Open exit (to go West) is an important precondition of the legitimacy of a constitution. But what should be done if exit is locked and the problem of the distribution of rights comes up. Musgrave proposes that the constitution framers should solve the 
distribution issue before they proceed to the allocation issue (Musgrave and Buchanan 2000). Once the problem of a just distribution is solved, the Wicksellian unanimity test may be applied and efficiency may be reached, but not before. But Musgrave remains silent on how the distribution problem should be solved. To re-introduce welfare economic judgements through the backdoor would certainly not be a satisfactory way. It would push economic analysis back behind Robbins' 1932 plead for an economics of choice. The problem is therefore not how to allocate resources, but how to define decision rules for allocating rights In a situation of conflict.

Rae (1969) and Taylor (1969) assume that an individual seeks to avoid having issues which he opposes imposed on him, but that he favours to impose issues he prefers on others so that, on the average, preferences can be assumed to be of equal intensity on both sides. Rae and Taylor ask: What rule does minimize the probability of supporting an issue that loses or opposing an issue that wins. The authors show that simple majority is the only rule that satisfies both criteria (Mueller 2003, p.136-7)

Brian Barry (1965) illustrates this case in a lucid example: Five people occupy a (once closed) railroad car. No sign either allows or prohibits smoking. Under the assumption of equal intensity of preferences and of uncertainty whether one is a smoker or a nonsmoker, majority rule is the best decision rule. It maximizes the expected utility of a constitutional decision maker (taken from Mueller 2003. p, 137).

The Rae Taylor rule shows that a constitutional contract is also feasible when individuals are locked-in. But simple majority rule becomes more attractive.1

\section{Federalism, competition and Public Choice}

A simple way to solve the public god problem is to privatize public goods. Charles. E. Tiebout (1956) has shown that local public goods can be privatized if localities are separated from each other. The problem of non-exclusion within a locality is avoided by exclusion between localities. It is thought that an individual pays a fixed access price to the community and consumes the good internally as a free public good. Competition among local communities guarantees an efficient supply at least costs. In the literature this form of pricing is known under the name two-part or Dinseyland pricing (W. Y. Oi, 1971)

Tiebout competition generates important adjustment processes. First, local communities will specialize in particular services and hence induce citizens with similar

1 Unanimity is also problematic if it conflicts with liberty. Amartya Sen (1970) has shown that Individuals may agree unanimously to prefer an alternative at the costs of liberty. What should be done? The resulting dilemma may be irresolvable. The conflict appears even more problematic when liberty is given up due to a constitutgionally agreed simple majority decision. 
preferences to cluster in specialized local communities. Second, as far as the market is a discovery process (Hayek 1968), local jurisdictions under competition will search for new products and processes, hence dynamically improve the quality of local public services. Third, competitive federalism is a laboratory for new ideas (Wallace Oates' "laboratory federalism" (1999)). Fourth, federalism may crowd out inefficient bureaucratic and Leviathan solutions (Weingast 1995); and fifth, federalism may bring a local community on a steeper growth path (Feld, Schnellenbach 2011).

The pure Tiebout model does not provide for public choice. Local governments work in the same way as markets work. They find the efficient solution themselves. Public choice is not only unnecessary, it would even interfere with the market and destroy Tiebout's efficiency. Public Choice can, however, help to support federalism where the latter is not strong enough to bring about an efficient spatial specialization.

Suppose that the 100.000 inhabitants of jurisdiction J, which consists of two local communities A and B with 55.000 and 45.000 inhabitants respectively, are debating the introduction of a progressive school system $X$ or a conservative school system $Y$, see table 1. If individuals are not motivated enough to segregate in specialized jurisdictions democracy can help to reveal citizens' preferences.

Table 1: Collective choice of school system $X$ and $Y$

\begin{tabular}{|c|c|c|}
\hline & \multicolumn{2}{|l|}{ Options } \\
\hline & School system X & School system $Y$ \\
\hline Inhabitants of $A$ & 20.000 & 30.000 \\
\hline Inhabitants of B & 35.000 & 15.000 \\
\hline All Inhabitants & 55.000 & 45.000 \\
\hline
\end{tabular}

Source: Wagner (1983), Blankart (2011) 
If Jurisdictions $A$ and $B$ vote in their between the two school systems, entity the progressive school system $X$ will be chosen. The preferences of 55.000 voters will be fulfilled, while 45.000 inhabitants are outvoted. If the inhabitants of $A$ and $B$ vote separately, however, the $A$ inhabitants would choose the conservative school system $Y$, while the B inhabitants would opt for the progressive school system $X$. As can be seen, only 35.000 inhabitants are outvoted: this is a clear advantage of decentralized voting (under the assumption that the inhabitants in A are equally concerned about school systems as those in B). Decentralized vote reveals that voters have different preferences.

Note that with the same overall, but another inter-local, distribution of votes, both communities might vote for the progressive school system so that decentralized decision making does not seem necessary. The equality of the two outcome is, however, not an argument against decentralized voting, for how could one know that an aggregated vote is enough if not proved by decentralized voting? Therefore it is more reliable to start with decentralized government before centralized solutions are considered. This insight has been anchored in Oates' decentralization theorem:

For a public good - the consumption of which is defined over geographical subsets of the total population, and for which the costs of providing each level of output of the good in each jurisdiction are the same for the central or the respective local government - it will always be more efficient (or at least as efficient) for local governments to provide the Pareto-efficient levels of output for their respective jurisdictions than for the central government to provide any specified and uniform level of output across all jurisdictions. (Oates 1972: ...)

The conclusion is that a democracy can support federalism where its own forces are not strong enough to bring about an efficient outcome, but that democracy cannot replace federalism; for how could the vote districts be formed without the prior evidence provided by federalism?

Oates' decentralization Theorem requires calculating the relative costs of alternative levels of government in each case. This is often too intricate. A more practical alternative is provided by the subsidiarity principle. The principle says that if a problem can be tackled individually or within an individual's family it should not be delegated to the local or a higher level government. The burden of the proof of centralization is always with the next higher entity. If the subsidiarity test is negative the issue remains with the lower level. The subsidiarity principle has been accepted as a general principle in politics. It is also embedded in art. $5 \mathrm{EU}$ of the Treaty of Lisbon: "The use of Union competences is governed by the principles of subsidiarity and proportionality." The subsidiarity principle is related to the principle of institutional congruency. Only when the citizens of a jurisdiction bear the full costs of a public service they can calculate rationally whether it is worthwhile to increase taxes for its extension or vice versa to 
decrease taxes. But if ambitious politicians believe that they can obtain power by redistributing costs they will not hesitate to do so. Therefore the subsidiarity principle is weak in politics. It is often violated to attract more votes.

\section{Multi-Level Constitutions}

Many constituencies try to restrict uncontrolled centralization by constitutional rules.

These rules are often not as consensual as in the model of Buchanan and Tullock, but exempt from day to day politics so that they can only be changed by consent of a qualified majority. Theory and practice of public choice have developed several models to restrict or at least to channel centralization. Three of which are of importance: The model of an association of states, the model of a federal state and the model of a unitary state (Blankart 2011).

In an association of states a motion to centralize an issue from a lower to a higher level of government is only adopted if it obtains a "gross majority", i.e. if it is adopted by majority of each member state according to its constitution. In a unitary state a "net majority" of all citizens, independent of their place of residence, is sufficient to centralize an issue. A federal state usually requires a qualified majority somewhere between a gross and net majority. The European Union as an association of states, the United States and Germany are federal states, and France is a unitary state. Therefore a centralization of government is more likely in the unitary state of France than in an association of states as the EU. On the other hand, it may be more difficult to control the decisions of governments of an association of states than the government of a unitary state, so that an association of states is not exempt of the danger of overcentralization.

\section{Which form of democracy?}

Citizens of an association of states, of a federal state and of a unitary state, may practice different forms of democracies. Some have direct democracies, some representative democracies and some two party systems. But which form of democracy should be chosen? In a direct democracy the voters vote on issues, in a representative democracy the voters elect representatives who vote on issues. These two cases, however, need to be defined more closely. A direct democracy means that a representative democracy is supplemented by direct voting if required by a referendum or an initiative, and a representative democracy means that the parliament exclusively and definitely decides. In some representative democracies, the government is elected by the parliament, in others the government or the president is elected directly by the citizens. Though both democracies are representative, the latter are often called "presidential".

Direct and representative democracies differ in the way how government and parliament are controlled. In a representative democracy members of parliament are confronted only at election time with voters' preferences. During the mandate they are 
are shielded from strict adherence to voters' will. In a direct democracy, in contrast, government and parliament have less leeway. They are checked by referenda and popular initiatives during the mandate and in the elections. Therefore more compliance with voter preferences has to be expected in direct democracies than in representative democracies.

An important question is therefore who does benefit from the leeway which is generated by voters' incomplete control in representative democracies? Economists say that the leeway establishes a common pool for which interest groups compete. In equilibrium the total costs of competition for rents are equal to the total benefits and nothing left over for interest groups (theorem of the dissipation of rents, Tullock 1980). Insofar as competition for rents is restricted rents do not fully dissipate and result in benefits for staff and bureaucrats within the government (Lüchinger, Meyer and Stutzer 2010). For these reasons interest groups have an important influence in representative democracies. But what about rents in a direct democracy? In general it is said that the political influence of interest groups and bureaucrats is smaller in a direct democracy than in a representative democracy for it is more expensive to convince millions of voters than a handful of representatives (Kirchgässner, Feld and Savioz 1999: 31-32).

Rent seeking is not without social costs to voters: what interest groups try to gain is lost by voters. Especially vaguely defined and blurred voter interests such as disguised taxes, general expenditures and public debt are likely to be neglected by politicians in parliamentary democracies in favour of interest groups' goals. Amilcare Puviani (1903) has observed this phenomenon more than a hundred years ago. In empirical studies it has been corroborated later that taxes, expenditures and public debt are significantly lower in direct than in parliamentary democracies (Kirchgässner, Feld and Savioz, 1999).

Rent-seeking occurs mostly in public production which cannot be easily controlled by voters. Quite a number of $19^{\text {th }}$ century French economists therefore argue for an outright privatization of state enterprises, for a transformation of the State into a new organization designed on the model of a private company. The state should disappear into a new private company (see Faccharello, 2010, for a survey). Obviously a well organizesd private economy is always better than a corrupt public economy. Therefore the state as a private company works only under appropriate regulation.

Blankart and Mueller (2014) ask: What could be done to improve citizens'representation? In practice we observe two forms of representation: a representative democracy can be either a pure representative democracy (PRD) or a pure two party system (PTP). PRD is aimed at representing citizens' preferences as truthfully as possible, PTP is aimed at voting on political issues.

In a pure representative democracy every citizen is regarded as a member of parliament. But as only a few citizens want to go to parliament, those who prefer to stay outside can transfer their vote in the election process to a person of their choice. This 
person can cast as many votes in the parliament as she or he has been transferred in the election. But this is only the first round of an election. It is followed in a similar way by a second round limited to those say 200 candidates who have received most votes in the first round and for whom there is space in the parliament. In the end a parliament is elected that represents as closely as possible the preferences of the population as a whole. This system of a pure representative democracy can be ideally combined with referenda and popular initiatives of a direct democracy. In fact, it makes sense to allow voters to check from time to time in a referendum or in an initiative whether the representatives are still faithful to voters' preferences. As such, the referendum has its right place.

In a true pure two party system (PTP) party leaders propose a platform of issues which they want to tackle during the next election round. After a first round with several parties and platforms a run-off vote is held between the two platforms which obtained most votes in the first round. The platform which receives more votes will be given the government. Note that PTP differs from the Westminster system (as known in the UK) as it always encompasses a majority of votes which the Westminster system does not. In PTP the winning party is responsible for its entire platform up to the next election. Therefore it is logical not to allow direct democracy through referenda and initiatives during the election period as they would blur government's responsibility.

In conclusion: If the society decides in favour of PRD (or a similar system targeted towards truthful representation of voters as e.g. in Germany) direct democracy by referenda and popular initiative are recommended and should not be prohibited. Policy results from discussion and debate in the parliament and may come more or less close to voters' true preferences. Hence, checks by referenda and initiatives can be helpful. Moreover, in PRD it is inconsistent to say that parliament's mandate does not allow interfering referenda or initiatives given that such a mandate was not the purpose of the antecedent election. The purpose of the election was to find voters' preferences and to represent them in the parliament and not to formulate a governmentprogram.

If one wants to exclude direct democracy, PTP should be chosen. The function of the parliament under PTP is to guarantee a majority for the government. It is not its task to formulate a policy by discussion and debate as the policy has already been chosen in the election.

In any case, the Westminster System fares worse than either PRD or PTP if individual preferences are taken as a reference. It is also not recommended to mix PRD and PTP in the Westminster system of majoritarian election. The Westminster System allows that the voters shift to the right while the government coalition shifts to the left or vice versa which is impossible under PRD and PTP (Blankart and Mueller 2014). 


\section{Parliamentary democracy and the political business cycle}

The temporary monopoly provided to governments in an election not only promotes a policy in favour of interest groups, it may also have a dynamic impact on promoting political business cycles.

This basic hypothesis has first been proposed by William D. Nordhaus (1975). In the elections, voters evaluate government's past ability to steer the economy between unemployment and inflation under the assumption of a Phillips curve. They weigh unemployment more negatively than inflation. The government can gain votes if it steers the economy in a way that unemployment is low at election time (even if inflation is somewhat higher). If, after the election, inflation has to be reduced again and unemployment increases, the government's popularity decreases. But before the next elections, voters will have forgotten these hardships and will vote again for the government if unemployment is low even if inflation is high.

These considerations are diametrically opposed to the traditional economic policy paradigm: whereas in traditional public finance it is assumed that a government controls its expenditures and revenues in a way that the economic fluctuations are dampened, Nordhaus concludes from his model that the government has incentives to generate these fluctuations. In other words, if the private sector of the economy does not generate these fluctuations on its own, then the government of a representative democracy, which has to be re-elected periodically, would cause them. Therefore, the attention of public choice economists should focus more on endogenous cycles than on exogenous cycles.

The Nordhaus hypothsesis has triggered an intense discussion. Three alternative models have been proposed: the partisan theory by Douglas A. Hibbs (1977), the theory of rational expectations by Alberto Alesina (1987) and an intermediary theory by Bruno $\mathrm{S}$. Frey and Friedrich Schneider (1978 a,b).

(a) Hibbs argues that parties have their partisans and they will support the interests of their partisans if they come to power. Hibbs, therefore, does not follow the Nordhaus (and Downs) hypothesis according to which parties make their programs according to vote maximization. In Hibbs' model parties follow a political science attitude in that they try to win an election with the ideology of their partisans. Left-wing parties pursue an expansive and inflationary labour market policy favouring inflation rather than unemployment for their lower middle class clientele. Right-wing parties pursue an opposite policy for their upper middle class clientele. As a consequence, Hibbs predicts a political business cycle when the governing party changes.

(b) Alesina and other proponents of the Political Economics School are critical of the theory of the political business cycle of Nordhaus whom they include in the Public Choice School. Their approach is "anti-public choice" (Blankart and Koester 2006). They argue that the Nordhaus Public Choice theories contradict the theory of rational 
expectations. A government acting as in the Nordhaus model, deceives systematically and permanently the voters. If e.g. the government pursues an inflationary policy to lower unemployment, it is allegedly assumed that workers do not understand that this policy is accompanied by a decrease in the real wage. Only with this illusion, will they be willing to work more, and only in this case, is a drift along the Phillips curve possible for the government. If, however, rational expectations are assumed, individuals do not evaluate the government on the performance in the expired legislative period, but rather on the impact that governmental actions will have in the future. The individuals see through the intentions of the government, do their appropriate disposals and attempt to block their impacts: e.g. unions will anticipate the inflation effects of an expansive tax and spending policy; they will not accept the decrease in real wages and therefore will demand higher wages, and similar, with the consequence that a positive employment effect will not be initiated and there will be no political business cycle.

Indeed it makes no sense why a government should try to create political business cycles. A political influence on the economic cycle - if suspected - has to be justified in another way. Alesina takes Hibbs' partisan theory as a starting point and introduces the assumption of an uncertain election outcome. Before the election, voters do not exactly know if a left-wing party with a preference for an expansive national budget or a right-wing party favouring a contractionary budget, will come to power. Therefore the citizens will behave carefully in their function as workers and union agents. They will assume an average budgetary policy for their wage claim if the labour agreement will hold beyond the election date. If one party comes to power there will be surprises and real (expansive or contractionary) impacts effects. From this perspective, politics will keep its influence on the economy. However, it remains an open question why workers with rational expectations do not adjust their labour agreements to the election dates so they could partly avoid surprises of the election outcome. Then there would be no political business cycles. Thus the question remains: Why do really rational unions and employers not adjust their negotiations to the election dates? So they could avoid surprises. In as much as Alesina leaves this question open, his unions do not seem to have fully rational expectations.

Dennis C. Mueller (2003: Chapter 19) puts the different models to the test and analyzes which one explains the U.S. business cycles between 1949 and 2000 better. The partisan theory of Hibbs performs best. If the president is a democrat, unemployment decreases whereas it increases if the president is a republican. The theories of political business cycles of Nordhaus perform slightly less satisfactory and the theoretically ambitious models of Alesina (in Alesina and Rosenthal 1995) perform definitely worse.

While Hibbs' partisan theory seemed to work well for the United States it was less successful for other countries. For Germany, Gerrit B. Koester (2009) shows that, contrary to the partisan theory, governments led by Social Democrats between 1994 and 2004 lowered the progressive income tax and increased the more regressive value added tax, while governments dominated by Christian Democrats behaved conversely. 
(c) An intermediate approach between Nordhaus and Alesina has been developed by Frey and Schneider $(1978 \mathrm{a}, \mathrm{b})$. In their theory, incentives of the government to become budgetary-politically active depend on the electoral-political need. This is given if elections are about to happen and the economic situation is bad. With a bad economic situation, e.g high unemployment or high inflation, the regularly measured popularity of the government is low. With upcoming elections the government sees itself forced to take immediate budgetary counteractions. In case of high unemployment it will raise the expenditures (especially transfers) and lower taxes. In case of high inflation it will lower the expenditures for goods and services and possibly raise taxes. In doing so, it hopes to win back lost popularity and to avoid an election loss. This case is illustrated in the upper left field in Table 2. In all other cases where either the economic situation is good and the popularity is high or no elections are upcoming, the government does not need to become politically active. The government can plan its incomes and expenditures in the long run dependent on is'ts ideology and does not have to directly consider the interests of the voters. The approach of Frey and Schneider has been successfully tested for different countries.

Table 2: Government budgetary policy dependent on election dates and economic situation

\begin{tabular}{|c|c|c|}
\hline & Upcoming elections & No upcoming eletion \\
\hline $\begin{array}{l}\text { Economic situation bad, } \\
\text { popularity low }\end{array}$ & $\begin{array}{l}\text { Active anticyclical } \\
\text { budgetary policy }\end{array}$ & $\begin{array}{l}\text { Ideological budgetary } \\
\text { policy }\end{array}$ \\
\hline $\begin{array}{l}\text { Economic Situation good, } \\
\text { popularity high }\end{array}$ & $\begin{array}{l}\text { Ideological budgetary } \\
\text { policy }\end{array}$ & $\begin{array}{l}\text { Ideological budgetary } \\
\text { policy }\end{array}$ \\
\hline
\end{tabular}

Source: Frey and Schneider (1978)

\section{Conclusions}

The purpose of public choice is to discover what a society of individuals prefers. $19^{\text {th }}$ century utilitarians thought that individual utilities could be measured and aggregated. This view has been refuted by Lionel Robbins (1932) who argues that only individual choices between ends and scarce means can uncover individual preferences. This new approach has opened the door to public choice. 
The first and still most significant scholar of public choice is Kenneth Arrow with his treatise on "Social choice and individual values" $(1951,1963)$. Arrow shows that consistent social preferences cannot be derived from individual wants, if they are to be compatible with four fundamental axioms: (i.) that the domain of individual preferences is to be unrestricted: (ii.) that dictatorship is to be absent, (iii.) that Pareto efficiency should be observed and that (iv.) the social preferences are independent of irrelevant alternatives. No society can fulfil all four axioms together. All societies of all times have to compromise.

The history of mankind can be regarded as a mirror of how people have coped with Arrow's axioms. Primitive societies of primeval times were mostly dictatorships. They disregarded the axiom of non-dictatorship as well as most of the other axioms. Later individuals became more mobile increasing their domain of individual preferences. But with different beliefs, they developed different ideologies which generated wars and other cruelties inflicting the Pareto axiom. This was an endless tragedy. Arrow's fourth axiom, the independence of irrelevant alternatives, however, seems immune against the intricacies of human conflicts. Arrow has introduced the independence axiom because he wanted to avoid comparisons between more than two alternatives and hence cardinal (strategic) evaluations (Arrow. 1963, p. 110). But the restriction to pairwise comparisons has its price. It leads directly into cyclical decisions if independence does not hold, in particular if issues are linked by externalities.

This can be illustrated by the actual euro crisis. If a bank is in a systemic interconnection with other banks a single drop out may generate a large and endless crisis. Suppose banker of county $X$ declares: "I fail", this is enough for the rest of the euro bankers to ask: Shall we survive? The approach the ECB to bail them out. The ECB bailout may encourage moral hazard of the first banker who starts a new round of failure and bailout etc. These sorts of externalities show that once the independence axiom is violated which an endless chain of crises may follow. The example illustrates the dismal message of Kenneth Arrow: A crisis is not an exception. It the ordinary stem of the tide.

\section{References}

Alesina, A. (1987), 'Macroeconomic Policy in a Two-Party-System as a Repeated Game', in: Quarterly Journal of Economics, 102, 651-678. 
Alesina A. und H. Rosental (1995), Partisan Politics, Divided Government and the

economy, Cambridge, Cambridge University Press.

Arrow, K. J. (1951, 1963), Social choice and individual values, New York: John Wiley, sd. ed. 1963.

Barry, B. (1965): Politcal Argument, London: Routledge 1965.

Bentham J. (1789), Introduction to the Principles of Morals and Legislation hrsg. von J. H. Burns/H.L.A. Hart, The Collected Works of Jeremy Bentham, $2 \mathrm{~d}$ ed. Oxford: Clarendon Press.

Bergson, A. (1938), 'A Reformulation of certain Aspects of Welfare Economics', Quarterly Journal of Economics 52 (7), 314-344.

Bernholz, P. (1978), 'On the stability of logrolling outcomes in stochastic games', Public Choice 33 (3), 65-82.

Black, D. (1948), 'On the Rationale of Group Decision Making', Journal of Political Economy, 56, February 23-34.

Blankart, Ch. B. (2011), Öffentliche Finanzen in der Demokratie (Public Finance in a Democracy) München: Vahlen 8th ed. 2012.

Blankart, Ch. B. (2012), 'Oil and vinegar. A fiscal theory of the euro crisis', in A..Varsori and M. Poettinger eds., Economic Crisis and New Nationalisms, Euroclio, Lang, Brussels 2014, pp. 99-113.

Blankart, Ch. B. and E. R. Fasten (2011), 'Knut Wicksell's Principle of Just Taxation Revisited' in: Volker Caspari ed.: The Evolution of Economic Theory: Essays in Honour of Bertram Schefold, London: Routledge, 2011, pp. 132-141.

Blankart, Ch. B. and G. Koester (2006), 'Political Economics versus Public Choice', Kyklos, vol. 59, 171-200.

Blankart, Ch. B. and D.C. Mueller (2004), 'The advantages of pure forms of parliamentary democracy over mixed forms', Public Choice vol. 122, 2004, 431-453.

Mueller, D.C. and Blankart, Ch. B. (2014), Wer soll die Bürger im Staat repräsentieren? ifo Schnelldienst 15/2014 - 67. Jahrgang - 14. August 2014, pp. 3-6.

Bernholz, P., "Logrolling, Arrow Paradox and Cyclical Majorities," Public Choice 15, Summer 1973, 87-95.

Blankart, Ch. B. An Institutional Theory of the Euro Crisis, Antonio Varsori \& Monika Poettinger (eds.) Economic Crisis and New Nationalisms, German Political Economy as Perceived by European Partners, P.I.E. Peter Lang s.a., éditions scientifiques internationals, Brussels, 2014, pp.99-114.

New Nationalisms, German Political Economy as Perceived by European Partners, P.I.E. Peter Lang s.a., éditions scientifiques internationals, Brussels, 2014, pp.99-114 
Blaug, M. (1978), Economic Theory in Retrospect, Cambridge: Cambridge Univ. Press 1978.

Buchanan, James. 1999. The Foundations for Normative Individualism. In: The Logical Foundations of Constitutional Liberty. Indianapolis: Liberty Fund.

Buchanan, J.M. und R.A. Musgrave (1999), Public Finance and Public Choice: Two Contrasting Visions of the State, MIT Press, Cambridge, Massachusetts.

Buchanan, J. M. and Tullock, G. (1962), The Calculus of Consent, Ann Arbor: University of Michigan Press.

De Condorcet Marie-Jean-Antoine-Nicolas Caritat (1785) Essai de l'application de l'analyse de la probabilité des décisions rendues à la pluralité des voix, Paris 1785.

Coughlin P. and S. Nitzan (1981), 'Electoral Outcomes with Probabilistic Voting and Nash Social Welfare Maxima', Journal of Public Economics, 15, 113-122.

De Viti De Marco, A. (1888), Il carattere teorico dell'economia finanziaria, Rom: Pasqualucci.

Diamond, P.A. und J.A. Mirrlees (1971), Optimal Taxation and Public Production I: Production Efficiency, and Optimal Taxation and Public Production II: Tax Rules, American Economic Review, Vol. 61, No. 1 and 2, 1971: 8-27 and 261-278.

Charles Dodgson, A Method of Taking Votes on more than two Issues (1865, reprinted in D. Black, Th Theory of Committees and Elections, Cambridge ( Cambridge Univ. Press) 1958.

Downs, A. (1957), An Economic Theory of Democracy, New York: Harper \& Row.

Feld, L.P. and Schnellenbach, J. (2011), Fiscal Federalism and Long-Run Macroeconomic Performance: A Survey of Recent Research (with Lars P. Feld). EPC: Government and Policy 29: 224-243.

Frey, B. S. and F. Schneider (1978), 'An empirical study of a politico-economic interaction in the U.S.', Review of Economics and Statistics, Vol. 60, May, 174-183.

Hayek, F.A. (1968), 'The market as a discovery procedure', translated and reprinted in: The Quarterly Journal of Austrian Economics, Vol. 5, No. 3, Fall 2002: 9-23.

Hibbs, D.A. (1977), 'Political parties and macroeconomic policy', American Political Science Review (71). December, 1467-1487.

Jevons, W.S. (1871), The Theory of Political Economy, London: Macmillan. 
Kirchgässner, G., Feld, L. and Savioz M. R. (1999), Direkte Demokratie. Modern, erfolgreich, entwicklungs- und exportfähig, Basel, München: Helbing und Lichtenhahn, Vahlen.

Koester, G. B. (2009), The political economy of tax reforms, Berlin: Humboldt-Universität zu Berlin, Baden-Baden: Nomos.

Kramer, G. H. (1973), 'On a class of equilibrium conditions for majority rule', Econometrica, 41(2), 285-297.

Lüchinger, S., Stutzer A. and Meier St. (2008), 'Bureaucratic Rents and Life Satisfaction', Journal of Law, Economics \& Organization: 24 (2), 476-488.

Luechinger, and Meier St. and Alois Stutzer, A. (2010), Why Does Unemployment Hurt the Employed?: Evidence from the Life Satisfaction Gap Between the Public and the Private Sector, Journal of Human Resources, University of Wisconsin Press, vol. 45(4): 998-1045.

May, K. O. (1952), 'A Set of Independent, Necessary and Sufficient Conditions for Simple Majority Decisions', Econometrica, 80, 680-684.

Ugo Mazzola: The Formation of Prices of Public Goods, in : A.T. Peacock und R.A. Musgrave, Classics in the Theory of Public Finance. Houndsmill, Macmillan 1958, pp. 37-47.

Menger, C. (1871), Grundsätze der Volkswirtschaftslehre, W. Braumüller, Wien.

D.C. Mueller (2003), Public Choice III, Cambridge, Cambridge Univ. Press (2003).

R.A. Musgrave (1939), 'The Voluntary Exchange Theory of Public Economy', Quarterly Journal of Economics, 53, pp. 213-237.

Nordhaus, W.D. (1975) 'The Political Business Cycle', Review of Economic Studies, Vol. $42,1975,169-190$.

Oates, W. E. (1972), Fiscal Federalism, London: Harcourt Brace.

Oates W. E. (1999), An Essay on Fiscal Federalism, Journal of Economic Literature, Vol. 37, No. 3. (Sep., 1999), pp. 1120-1149

Oi, W. Y. (1971), A Disneyland Dilemma: Two-Part Tariffs, The Quarterly Journal of Economics, Vol. 85, No. 1 (Feb., 1971), pp. 77-96.

Plott, Ch. R. (1967), 'A Notion of Equilibrium and Its Possibility under Majority Rule', American Economic Review, 57, September, 787-806.

Puviani, A. (1903), Teoria della illusione finanziaria, Mailand, Remo Sandro, in German: Die Illusion in der öffentlichen Finanzwirtschaft, mit einer Einführung von G. Schmölders, Berlin, Duncker und Humblot, 1960. 
Rae, D. W. (1969), 'Decision-Rules and Individual Values in Constitutional Choice', American Political Science Review, 63, 40-56.

Robbins, L. $(1932,1935)$ An Essay on the Nature and Significance of Economic Science, London (Macmillan)

Samuelson, P. (1947), Foundations of Economic Analysis, Cambridge: Harvard University Press.

Taylor Michael D, "Proof of a theorem on Majority rule, in: Behavioral Science 24, May 2969, 228-231.

Tiebout, C. M. (1956), 'A Pure Theory of Local Expenditures', Journal of Political Economy, 64, 416-424.

Tullock, G. (1980), 'Efficient Rent-Seeking', in J.M. Buchanan, R. Tollison and G. Tullock editors, Toward a Theory of the Rent-Seeking Society, College Station: Texas A\&M University Press: 97-112.Tullock G., (1967) : "The Welfare Costs Of Tariffs, Monopoly and Theft", Western Economic Journal, vol . 5, 224-232.

Tullock, G. (1967), Toward Mathematics of Politics, Ann Arbor: University of Michigan Press.

Tullock, G. (1971), 'The Paradox of Revolutions', Public Choice 11, 89-100.

Tullock G. (1967), 'The welfare costs of tariffs, monopoly and theft' Western Economic Journal, Vol 5, 1967, pp. 224-232.

Wagner, R.E. (1983), Public Finance, Revenues and Expenditures in a Democratic Society, Boston, Toronto: Little, Brown and Comp.

Walras, L. (1874), Eléments d'économie politique pure ou théorie de la richesse sociale, Paris (Pichon et Duriaz-Anzias) 1874 to 1877, last ed. 1926.

Weingast, B.R. (1995), 'The Economic Role of Political Institutions: Market Preserving Federalism and Economic Development', in: Journal of Law Economics and Organization, Vol. 11, 2571-2588.

Wicksell, K. (1896), Finanztheoretische Untersuchen nebst Darstellung und Kritik des Steuerwesens Schwedens, Jena: Gustav Fischer. 